\title{
KONSEP HIJAU: PENERAPAN GREEN CONSTITUTION DAN GREEN LEGISLATION DALAM RANGKA ECO-DEMOCRACY
}

\author{
Eko Nurmardiansyah \\ email: nurmardiansyah@bdg.centrin.net.id
}

\begin{abstract}
Green principle is to be understood as a commitment to the environment. It is part of a broader ideology that places human relationship with the natural world at the center. Green is a process, not a status, a verb, not an adjective. Good environmental awareness become an important and urget global discourse. Eco-crasy should become the guiding principle informing Indonesian' state policy making (political law) in environmental protection and management. However, the concept of Ecocrasy should be further spelled out into a green constitution, green legislations and green budgeting.
\end{abstract}

Keywords:

Ecological democracy (eco-democracy/eco-cracy), Ecological Intelligence, Green Constitution, Green Legislation, Green Budgeting

\begin{abstract}
Abstrak
Prinsip hijau adalah komitmen terhadap lingkungan. Prinsip ini bagian dari ideologi yang lebih luas yang menempatkan hubungan manusia dengan alam sebagai titik tolak utama. Hijau adalah sebuah proses, bukan status, kata kerja, bukan kata sifat. Kesadaran lingkungan yang baik menjadi wacana global yang penting dan mendesak. Ide Eco-crasy harus menjadi pedoman dalam pembuatan kebijakan negara (politik hukum) di Indonesia berkenaan dengan perlindungan dan pengelolaan lingkungan hidup. Konsep Eco-cracy agar dapat dieksekusi dalam sistem negara, perlu dijabarkan dalam konstitusi hijau, legislasi hijau dan penganggaran yang juga hijau.
\end{abstract}

Kata kunci: Demokrasi ekologis (eco-demokrasi/eko-krasi), Intelijen Ekologis, Hijau Konstitusi, Hijau Legislasi, Anggaran Hijau

\section{Pendahuluan}

Pada saat ini banyak istilah-istilah yang ditampilkan dan digunakan dengan mengaitkan kata green, seperti green politics, green party, green banking, greendeen (green religion), green market, green building, green democracy, green constitution, green legislation, green budget, green economic, green bench, bahkan Provinsi Jawa Barat sekarang ini mengklaim diri sebagai green province (provinsi hijau), yaitu provinsi yang berwawasan lingkungan atau Kota Bandung sebagai green city (kota hijau), yaitu kota yang berwawasan lingkungan. Kota hijau (green city) yang memiliki banyak sebutan yang sejatinya senapas, seperti kota taman 
(garden city), kota berkelanjutan (sustainable city), kota ekologi (ecocity) dan kota simbiosis (symbiocity), akan dapat dicapai secara optimal jika dalam perencanaan dan implementasi pembangunannya dilaksanakan dengan cara memadukan tiga pilar utama pembangunan secara berimbang, yaitu ekonomi, sosial, dan ekologi.

Prinsip hijau yaitu memiliki komitmen terhadap lingkungan sebagai bagian dari ideologi yang lebih luas yang menempatkan hubungan kemanusiaan dengan dunia alam sebagai dasar, dengan konsekuensi meningkatkan efisiensi dalam aktivitas pembangunan tanpa mengorbankan kelestarian lingkungan, dan bukan apa yang dikemukan oleh Daniel Goleman dalam bukunya, Ecological Intelligence: The Coming Age of Radical Transparency, yang menjabarkan bahwa begitu banyak produk yang diberi label "green" hanya omong kosong belaka, dan menyoroti ketidakkonsistenan manusia dalam menanggapi krisis ekologis. Produk-produk yang diberi label "green" tersebut sebenarnya menurut Daniel Goleman tergolong greenish (kehijau-hijauan) - yaitu "draped with the mere appearance of ecological merit", dihiasi dengan penampilan yang seakan ramah lingkungan. ${ }^{1}$ Kegandrungan kita terhadap segala sesuatu yang ramah lingkungan menurut Daniel Goleman merepresentasikan tahap transisi (a transitional stage), yaitu "a dawning of awareness of ecological impact but one that lacks precision, depth of understanding, and clarity", yaitu munculnya kesadaran terhadap dampak ekologis tetapi masih kurang dalam hal ketepatan, kedalaman pemahaman, serta kejelasan. ${ }^{2}$ Umumnya apa yang digembor-gemborkan sebagai "hijau" pada kenyataannya hanya suatu fantasi atau sesuatu yang dibesar-besarkan. Standar "kehijauan" yang sekarang ada itu mungkin kelak akan dianggap eko-miopia (eco-myopia), yaitu pandangan yang dangkal terhadap lingkungan. ${ }^{3}$ Daniel Goleman berpendapat: "Green is a process, not a status - we need to think of "green" as a verb, not an adjective. That semantic shift help us focus better on greening." ${ }^{4}$ Hijau adalah suatu proses (a

\footnotetext{
${ }^{1}$ Daniel Goleman, Ecological Intelligence: The Coming Age of Radical Transparency, (Penguin Books Ltd, London, England, 2009), hlm. 25.

2 Daniel Goleman, Id.

${ }^{3}$ Daniel Goleman, Id, hlm. 26.

${ }^{4}$ Daniel Goleman, Id, hlm. 28.
} 
process), bukan status, yang perlu dimaknai sebagai suatu kata kerja (a verb), bukan sebagai kata sifat (an adjective), yang mungkin dapat membantu kita untuk lebih fokus pada upaya ramah lingkungan.

Thomas L. Friedman pun mempertegas terkait dengan kata "hijau" dalam bukunya, Hot, Flat, and Crowded: Why We Need Green Revolution, bahwa "hijau" bukan lagi sebuah keisengan, hijau bukan lagi sebuah basa-basi, hijau bukan lagi sesuatu yang dianggap baik ... . Hijau sekarang adalah cara tumbuh, cara membangun, cara merancang, cara berproduksi, cara bekerja, dan cara hidup agar lebih baik. ${ }^{5}$ Hijau menurut Thomas L. Friedman berarti beranjak dari basa-basi ke yang lebih baik, dari sesuatu yang dipilih menjadi keharusan, dari sebuah keisengan menjadi sebuah strategi untuk menang, dari sebuah masalah tak terpecahkan menjadi sebuah peluang besar. 6 Apa pun yang dapat diperbuat untuk melaksanakan gaya hidup hijau menurut Thomas L. Friedman akan menjadikannya lebih kuat, lebih sehat, lebih aman, lebih inovatif, lebih kompetitif, dan lebih dihormati.7 Itu sebabnya Thomas L. Friedman, mengatakan bahwa hijau adalah merah, putih, dan biru yang baru: karena ini strategi yang dapat membantu meredakan pemanasan bumi, kerusakan keanekaragaman hayati, kemiskinan energi, kediktatoran minyak, dan kekurangan pasokan energi. Kita memecahkan masalah kita sendiri dengan membantu dunia memecahkan masalah-masalahnya. ${ }^{8}$

Daniel Goleman menerangkan mengapa manusia sebagai pembeli tidak tahu-menahu mengenai dampak tersembunyi barang-barang dan jasa yang kita pakai. Pembeli juga menjadi korban dari tak tersedianya informasi tentang efek merugikan yang timbul dari proses produksi, pengiriman, pengemasan, pendistribusian, dan pembuangan barang-barang yang dibeli. Tetapi kini kekuatan berada di tangan pembeli bukan lagi di tangan penjual, karena generasi baru teknologi memberi kita informasi tentang fakta-fakta ekologis berbagai produk

\footnotetext{
5 Thomas L. Friedman, 2009, Hot, Flat, and Crowded: Why We Need Green Revolution, Penerbit PT. Gramedia Pustaka Utama, Jakarta, hlm. 237.

6 Thomas L. Friedman, 2009, Id.

7 Thomas L. Friedman, 2009, Id, hlm. 238.

8 Thomas L. Friedman, 2009, Id, hlm. 238.
} 
yang akan kita beli. Daniel Goleman menyebutnya sebagai radical transparency (transparansi radikal). ${ }^{9}$ Transparansi radikal menurut Daniel Goleman artinya menelusuri setiap dampak berarti dari suatu produk, mulai dari pembuatan hingga pembuangan-tidak hanya jejak karbon dan efek-efek lain terhadap lingungan, tetapi juga risiko biologis yang ditimbulkannya, termasuk juga konsekuensinya terhadap buruh yang membuat-lalu merangkum dampak tersebut bagi pembeli yang akan menentukan apa yang akan dibeli. ${ }^{10}$ Transparansi radikal ini memungkinkan konsumen membuat keputusan yang lebih cerdas dalam membeli, dan akan mendorong perusahaan-perusahaan untuk berpikir ulang dan memperbaharui bisnisnya yang akan mengantarkan kita ke era baru keuntungan kompetitif.

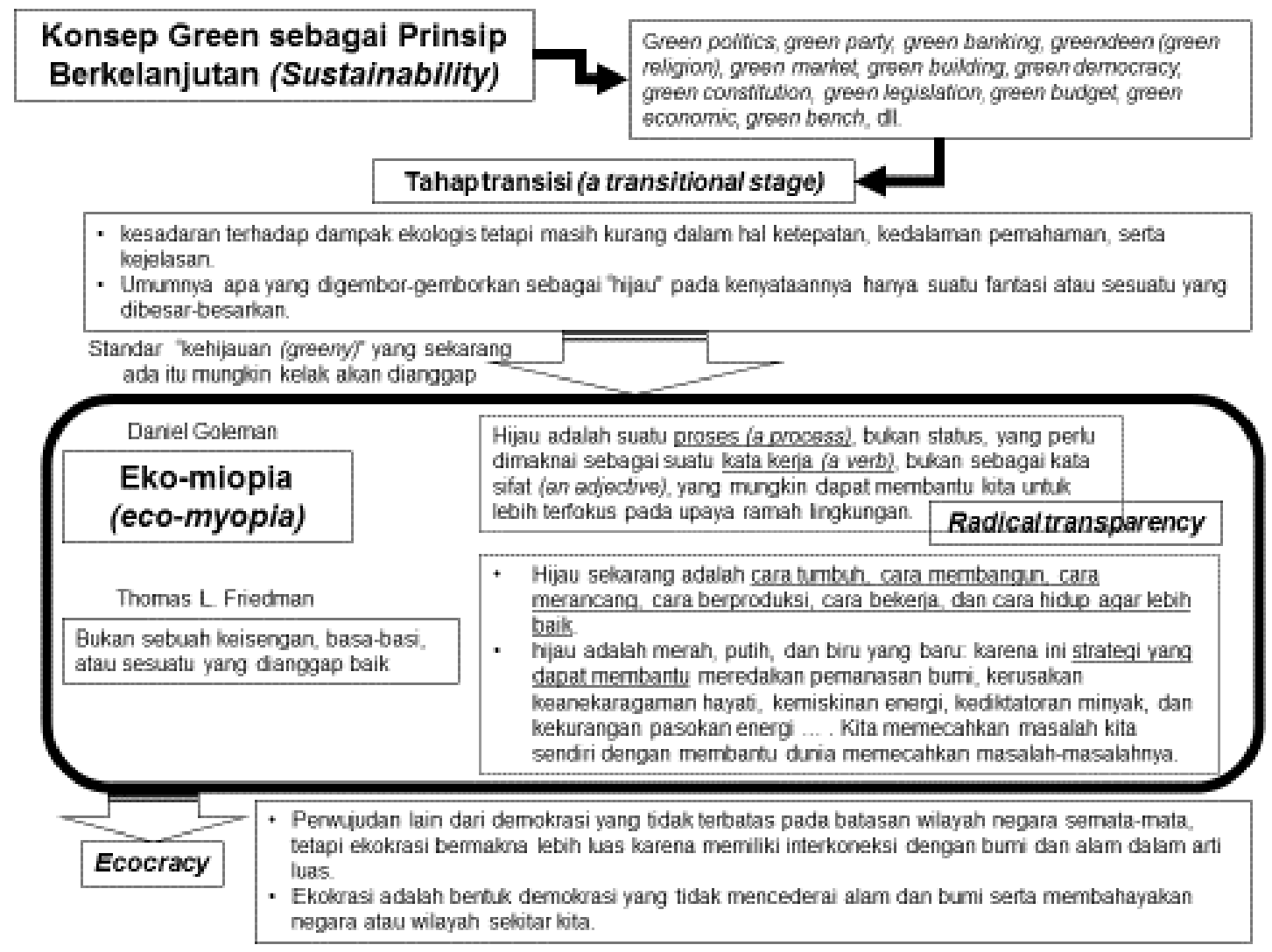

Gambar 1: Konsep Green sebagai Prinsip Berkelanjutan (Sustainability).

9 Daniel Goleman, Supra Catatan No. 5, hlm. 79.

${ }^{10}$ Daniel Goleman, Id. 
Daniel Golemen mengungkapkan "the sense in which we can, together, become more intelligent about the ecological impacts of how we live - and how ecological intelligence, combined with marketplace transparency, can create a mechanism for positive change."11 Cara menjadi cerdas dalam melihat dampak ekologis dari cara hidup manusia - dan bagaimana kecerdasan ekologis, bersamasama dengan transparansi pasar, dapat menciptakan suatu mekanisme bagi perubahan yang positif.

Penggunaan kata hijau (green) menurut pendapat Penulis adalah suatu proses (a process), bukan status, yang perlu dimaknai sebagai suatu kata kerja (a verb), bukan sebagai kata sifat (an adjective), yang mungkin dapat membantu kita untuk lebih terfokus pada upaya ramah lingkungan sebagaimana disampaikan oleh Daniel Goleman. Guna memperjelas uraian konsep hijau dari Daniel Goleman dan Thomas L. Friedman sebagai penerapan prinsip pembangunan berkelanjutan di atas, dan untuk lebih mempermudah pembaca, dapat dilihat melalui Gambar 1.

\section{Keterkaitan Konsep Hijau dengan Demokrasi Hijau (green democracy) atau Demokrasi ekologis (eco-democracy)}

Konsep hijau berkait erat dengan demokrasi hijau (green democracy) atau demokrasi ekologis (eco-democracy). Peristilahan demokrasi hijau (green democracy) atau demokrasi ekologis (eco-democracy) berkaitan erat dengan Brundtland Report yang melahirkan terminologi "ecocracy" dalam perkembangan beberapa konstitusi hijau (green constitution) di beberapa negara. Ecocracy merupakan kependekan dari kata ecological democracy atau eco-democracy. Ecocracy sebagai sebuah terminologi baru lebih dimaknai sebagai pengakuan atas alam dan lingkungan serta hal-hal yang terkandung di dalamnya. Juga memaknai akan keterbatasan daya dukung lingkungan serta pemahaman tentang sustainability ecology agar manusia tidak melakukan tindakan yang eksploitatif dan menghancurkan lingkungan serta alam ini dengan tanpa memprediksi

\footnotetext{
11 Daniel Goleman, Id, hlm. 3.
} 
konsekuensi dan dampak negatifnya. Makna tersebut mengacu pada konsep ekokrasi yang disampaikan oleh Henryk Skolimowsky dengan filsafat lingkungan (eco-philosophy)-nya, yang mempertimbangkan hubungan antara satu individu dengan yang lainnya dan juga dengan lingkungan mereka. ${ }^{12}$ Dengan demikian, ekokrasi adalah perwujudan lain dari demokrasi yang tidak terbatas pada batasan wilayah negara semata-mata, tetapi ekokrasi bermakna lebih luas karena memiliki interkoneksi dengan bumi dan alam dalam arti luas. Ekokrasi adalah bentuk demokrasi yang tidak mencederai alam dan bumi serta membahayakan negara atau wilayah sekitar kita. Bahkan, lebih jauh Jacqueline Aloisi de Larderel ${ }^{13}$ mengemukakan bahwa ekokrasi dapat dipandang dari perspektif sistem aktivitas yang memiliki parameter 'environmental protection' melalui standar-standar internasional secara komprehensif. ${ }^{14}$ Bumi, alam sekitar yang berisi manusia, hewan dan tumbuhan dipersepsikan sebagai sebuah kesatuan yang integratif dalam apa yang disebut sebagai keramahan terhadap alam.

Demokrasi permusyawaratan ala Indonesia yang mengandung visi "demokrasi deliberatif" memiliki daya antisipatif terhadap perkembangan kontemporer yang berkaitan dengan krisis ekologis. Seperti yang kerap diingatkan oleh para pendukung "demokrasi ekologis" (eco-democracy), krisis lingkungan, seperti dalam bentuk pemanasan global, tidak sekadar masalah lingkungan, melainkan menyangkut pula ikhwal kompleksitas demokrasi dan masalah keadilan. Contohnya, efek rumah kaca lebih merupakan masalah yang disebabkan oleh minoritas kaya di antara warga dunia. Berdasarkan pada pendapatan perkapita, beberapa negara menghasilkan emisi penyumbang pemanasan global dalam skala ratusan bahkan ribuan kali daripada negara-negara miskin. Bahkan di

\footnotetext{
${ }^{12}$ Henryk Skolimowski, 1981, Eco-philosophy: Designing New Tactics for Living, Marion Boyars Inc., New Hampshire, United States of America.

13 Jacqueline Aloisi de Larderel, after working for 15 years in the French Ministry of Environment, joined the United Nations Environment Programme (UNEP) in 1987 and assumed the position as Director of the Division of Technology, Industry and Economics (DTIE) until she retired in 2003. In 2001 she was also appointed Assistant Executive Director of UNEP.

14 Jacqueline Aloisi de Larderel, 1999, Living in an Ecocracy, United Nations Environment Programme, Paris, hlm. 67.
} 
dalam negara itu sendiri, mereka yang hidup berlebihan kerap merupakan donatur terbesar emisi daripada warga senegaranya yang hidup di bawah garis kemiskinan. Krisis ekologi merupakan salah satu cerminan kebuntuan demokrasi ekonomi. ${ }^{15}$

Untuk itu diperlukan suatu struktur politik yang bersahabat dengan lingkungan. Struktur politik yang bersahabat dengan lingkungan ini pada gilirannya memerlukan penghayatan "nilai-nilai hijau" di antara anasir-anasir dalam struktur tersebut. Karena itu, Robyn Eckersley ${ }^{16}$ mengambil kesimpulan bahwa kunci transformasi politik hijau ialah penyebarluasan dan penghayatan budaya ekosentris (berporos pada ekologi), di atas struktur politik yang sudah pula hijau. Inilah satu demokrasi yang menolak pendekatan either/or tetapi memeluk pendekatan both/and dalam debat prosedur - substansi - melingkupi baik struktur maupun nilai-nilai, sehingga demokrasi ekologis adalah demokrasi yang keluar dari teori-teori demokrasi terdahulu ketika demokrasi hanya berkutat pada hubungan manusia. Menurut John S. Dryzek, demokrasi ekologis menjadi suatu demokrasi yang berusaha memikirkan ulang tentang kecongkakan antroposentrisme (berporos pada manusia) sebagai hasil kesadaran keberadaan krisis ekologis. ${ }^{17}$

Demokrasi ekologis memerlukan ruang tempat mengaktualisasikan diri. Karena sifat anti-antroposentrisnya, perlu dipikirkan suatu bentuk sistem demokrasi yang tidak ketat dalam menetapkan batas teoretisnya. Sistem dan teori demokrasi yang ada, termasuk demokrasi liberal, hidup dalam batasan yang ketat antara manusia dan non-manusia, juga batasan yang rigid antara yang privat dan yang publik. Dalam situasi demikian, demokrasi ekologis yang melampaui batasan antara manusia dan alam dengan non-antroposentrisme, membuatnya susah berkembang dalam dekapan demokrasi liberal.

\footnotetext{
15 Yudi Latif, 2011, Negara Paripurna: Historisitas, Rasionalitas, dan Aktualitas Pancasila, Penerbit PT. Gramedia Pustaka Utama, Jakarta, hlm. 466.

16 Robert Eckersley, 1992, Environmentism and Political Theory, State University of New York Press, Albany.

17 John S. Dryzek, 2000, Deliberative Democracy and Beyond, Oxford University Press, New York, hlm. 6 .
} 
Kebanyakan pemikir demokrasi ekologis menengarai bahwa demokrasi musyawarah (deliberative democracy) merupakan wadah yang bisa mengakomodasi dan memanifestasikan nilai-nilai ekologis. Apalagi demokrasi ekologis menempatkan komunikasi sebagai modus mengadanya.

Demokrasi musyawarah dibangun berlandaskan akal-kearifan ketimbang kuasa, serta bersandarkan pada prosedur musyawarah sebagai cita-cita kebenaran politik. Legitimasi politik dalam demokrasi tidak diserahkan semata pada mayoritas saja karena justifikasi kekuasaan politik didasarkan lebih pada institusionalisasi partisipasi publik secara merdeka yang melibatkan warga negara yang setara dan mandiri. Karena itu, partisipasi politik publik diukur dari tingkat partisipasinya dalam bermusyawarah - inilah noktah penting demokrasi musyawarah. Demokrasi musyawarah karena itu, bukan menjadi sarana perwakilan atau pengumpulan pelbagai kepentingan melainkan sebagai suatu arena tempat segala permasalahan diselesaikan melalui dialog ketimbang penggunaan kekuasaan sebagaimana dikemukakan oleh Anthony Gidden. ${ }^{18}$

Oleh karena itu, demokrasi musyawarah menempatkan esensi demokrasi bukan pada voting, atau pengelompokan kepentingan, tetapi didasarkan pada musyawarah kolektif dan prosedur pengambilan keputusan yang terbuka. Sebagaimana John S. Dryzek tengarai, belokan musyawarah dalam teori demokrasi ini mewujudkan suatu pembaruan dari kompromi terhadap otentisitas yang telah lama dilupakan, yakni derajat kendali demokrasi yang benar-benar subtansial dan bukan sekadar simbolis. 19

Musyawarah memberikan kesempatan bagi nilai-nilai maupun pemikiran pro-lingkungan untuk mengemuka. Sifat terbuka dari prosedur demokrasi musyawarah yang lebih mementingkan rasionalitas argumen dan kearifan menempatkan kemungkinan lebih besar bagi diterimanya nilai-nilai dan pemikiran ekologis. Segala bentuk distorsi demokrasi, seperti hilangnya

\footnotetext{
${ }^{18}$ Anthony Gidden, 1994, Beyond Left and Right: the Future of Radical Politics, Stanford University Press, Stanford, hlm. 16.

${ }^{19}$ John S. Dryzek, 2000, Deliberative Democracy and Beyond, Oxford University Press, New York, hlm. 1.
} 
representasi di bawah kepentingan lobi, dapat diluruskan oleh rujukan rasional objektif yang diemban oleh demokrasi musyawarah. Karena itu, demokrasi musyawarah (deliberative democracy) secara intrinsik lebih terbuka pada penalaran etis yang berkembang dalam pemikiran ekologis. Dalam kaitan ini, Robert Eckersley ${ }^{20}$ berpendapat bahwa perspektif jangka pendek dari para pengambil keputusan dalam sistem demokrasi liberal membuat pertimbangan lingkungan ditinggalkan dalam kompetisi untuk mendapatkan kekuasaan. Karena itu, apabila demokrasi benar-benar ingin memasukkan pertimbangan lingkungan, ia harus memastikan bahwa musyawarah (dan bukan kompetisi) yang menjadi penentu dalam struktur ataupun proses pengambilan keputusan dalam berdemokrasi.

Konsep ekokrasi harus menjadi kaidah penuntun dalam pembuatan kebijakan negara (politik hukum) dalam perlindungan dan pengelolaan lingkungan hidup. Konsep ekokrasi agar dapat dijalankan dalam sistem bernegara, maka perlu dijabarkan dalam green constitution, green legislation serta green budgeting.

\section{Hak Atas Lingkungan Hidup yang Baik dan Sehat Merupakan Bagian dari Hak Asasi Manusia}

Lingkungan hidup merupakan isu terpenting dalam kehidupan manusia. Lingkungan hidup adalah realitas yang harus dijaga, dirawat dan dikembangkan sedemikian rupa untuk menunjang kesuksesan hidup manusia, baik secara fisik maupun mental. Tidak dapat terpikirkan bagaimana realitas kehidupan "anak manusia" masa kini dan ke depan apabila lingkungan hidup mengalami degradasi yang memprihatinkan.

Majda El Muhtaj menyatakan bahwa harus dipahami bahwa kebijakan untuk menegakan hukum atas kejahatan lingkungan merupakan sumbangan berharga bagi pelestarian alam Indonesia. Kejahatan alam dan lingkungan hidup

${ }^{20}$ Robert Eckersley, 2004, The Green State: Rethinking Democracy and Sovereignty, MIT Press, MA, Cambrigde. 
merupakan kejahatan konstitusional, yaitu hak asasi manusia untuk mendapatkan lingkungan yang baik dan sehat, sebagaimana diamanatkan dalam Pasal 28H UUD NRI Tahun 1945.21 Konstitusionalitas HAM atas lingkungan hidup semakin dipertegas dengan diundangkannya UU 32 Tahun 2009 sebagaimana telah dijelaskan diawal. UU 32 Tahun 2009 menjadi babak baru hadirnya pengakuan dan jaminan perlindungan HAM atas lingkungan hidup. Pasal 1 huruf a UU 32 Tahun 2009 menyatakan:

"Lingkungan Hidup adalah kesatuan ruang dengan semua benda, daya, keadaan dan makhluk hidup termasuk manusia dan perilakunya, yang mempengaruhi alam itu sendiri, kelangsungan perikehidupan, dan kesejahteraan manusia serta makhluk hidup lain."

Adapun yang dimaksud dengan perlindungan dan pengelolaan lingkungan hidup adalah upaya sistematis dan terpadu yang dilakukan untuk melestarikan fungsi lingkungan hidup dan mencegah terjadinya pencemaran dan/atau kerusakan lingkungan hidup yang meliputi perencanaan, pemanfaatan, pengendalian, pemeliharaan, pengawasan, dan penegakan hukum.

Penegasan penting lainnya, sebagaimana tercantum dalam Pasal 3 huruf g UU 32 Tahun 2009 yang menyatakan:

"Perlindungan dan pengelolaan lingkungan hidup bertujuan untuk menjamin pemenuhan dan perlindungan hak atas lingkungan hidup sebagai bagian dari hak asasi manusia."

Serta Pasal 65 ayat (1) UU 32 Tahun 2009 yang menyatakan:

"Setiap orang berhak atas lingkungan hidup yang baik dan sehat sebagai bagian dari hak asasi manusia."

Lingkungan hidup dan hak asasi manusia (HAM) menurut Mas Achmad Santosa memiliki keterkaitan yang sangat erat (close link) yaitu pelanggaran HAM seringkali merupakan penyebab dari degradasi lingkungan, di sisi lain, penurunan

21 Majda El Muhtaj, Dimensi-dimensi HAM: Mengurai Hak Ekonomi, Sosial, dan Budaya, Penerbit PT. Raja Grafindo Persada, Jakarta, 2009, hlm. 192. 
daya dukung lingkungan (ekosistem) mengakibatkan pelanggaran HAM. ${ }^{22}$ HAM atas lingkungan hidup merupakan hak fundamental manusia. Hak itu melekat sebagai yang memperkuat konstruk kehidupan manusia menurut Majda El Muhtaj. ${ }^{23}$ Hak atas lingkungan hidup yang bersih, menurut Christian Tomuschat termasuk dalam kategori generasi ketiga. Ada tiga jenis hak dalam kategori ini, yakni hak atas pembangunan (right to development), hak atas perdamaian (right to peace), dan hak atas lingkungan hidup yang bersih (right to a clean environment). Generasi ketiga HAM ini, biasanya dikenal sebagai hak solidaritas (solidarity rights). ${ }^{24}$

Tiga generasi HAM dikembangkan oleh Ahli Perancis Karel Vasak, dengan diilhami oleh Revolusi Perancis, oleh Karel Vasak HAM dibagi menjadi tiga generasi sebagai berikut: (a) generasi pertama, hak-hak sipil dan politik (liberte); (b) generasi kedua, hak-hak ekonomi, sosial, dan budaya (egalite); dan (c) generasi ketiga, hak-hak solidaritas (fraternite). ${ }^{25}$ Generasi ketiga yang mencakup hak-hak solidaritas (solidarity rights).

Pembagian hak asasi manusia tidak saja berdasarkan generasi sebagaimana dikemukakan oleh Christian Tomuschat dan Karel Vasak terdapat pula pembagian yang dikemukakan oleh Roy Gregory dan Philip Giddings. Roy Gregory dan Philip Giddings membagi hak asasi menjadi dua bagian, yaitu hak substantif (substantive rights) dan hak prosedural (procedural rights) dengan menyatakan: "Citizenship may be perceived in terms of the possession and exercise of a wide range of rights. In this context, rights take various forms, which can be considered in two categories: substantive and procedural."26 Menurut pendapat Roy

22 Mas Achmad Santosa, Hak Asasi Manusia dan Lingkungan Hidup, dalam ICEL Staff Articles, Indonesian Center for Environmental Law (ICEL), Jakarta, 1997.

23 Majda El Muhtaj, Supra Catatan No. 26, hlm. 193.

24 Christian Tomuschat, Human Rights Between Idealism and Realism, Oxford University Press, Oxford, 2003, hlm. 48.

25 Weston, Burns H., Richard A. Falk, dan Anthony D'Amato, International Law and World Order: A Problem - Oriented Coursebook, Saint Paul, West Publishing Co, 1990, hlm 18.

26 Roy Gregory dan Philip Giddings, 2001, Citizenship, Rights and the EU Ombudsman, dalam Richard Bellamy dan Alex Warleigh (editor), Citizenship and Governance in the European Union, Continuum, London-New York, hlm. 73. 
Gregory dan Philip Giddings tersebut bahwa kewarganegaraan akan dirasakan dengan adanya pengakuan dari sisi kepemilikan dan pelaksanaan berbagai macam hak asasi manusia. Hak dalam berbagai bentuk tersebut dapat dibagi dalam dua kategori yaitu hak substantif dan hak prosedural.

Kategori substantif menurut Roy Gregory dan Philip Giddings terdiri atas hak asasi 'generasi pertama' dan kebebasan asasi (fundamental freedoms), seperti kebebasan dari perbudakan (freedom from slavery), penyiksaan (torture) atau kekejaman (cruel), yang memperlakukan dan merendahkan martabat manusia. Bagian yang merupakan dari hak asasi manusia 'generasi pertama', tetapi lebih sempit yaitu yang sifatnya sipil dan politis (civil and political in character), adalah hak yang dibutuhkan untuk kebebasan individu, seperti kebebasan berbicara dan berserikat (freedom of speech and association), kebebasan untuk memiliki harta benda (to own property) dan kebebasan untuk berpartisipasi dalam pelaksanaan kekuasaan politik (to participate in the exercise of political powers). Selanjutnya dalam kategori substantif 'generasi kedua' adalah apa yang disebut dengan hak: sosial, ekonomi dan budaya, seperti hak untuk layanan kesehatan dan kesejahteraan yang wajar. Lebih kontroversial lagi, hak asasi manusia 'generasi ketiga', seperti hak-hak kolektif dari suku minoritas (the collective rights of ethnic minorities), hak atas pembangunan ekonomi (the right to economic development) dan hak untuk lingkungan hidup yang baik (the right to a good environment) sebagaimana yang telah dikemukakan di awal. Guna memperjelas uraian Generasi Hak Asasi Manusia di atas, dan untuk lebih mempermudah pembacaan, dapat dilihat melalui Gambar 2. 


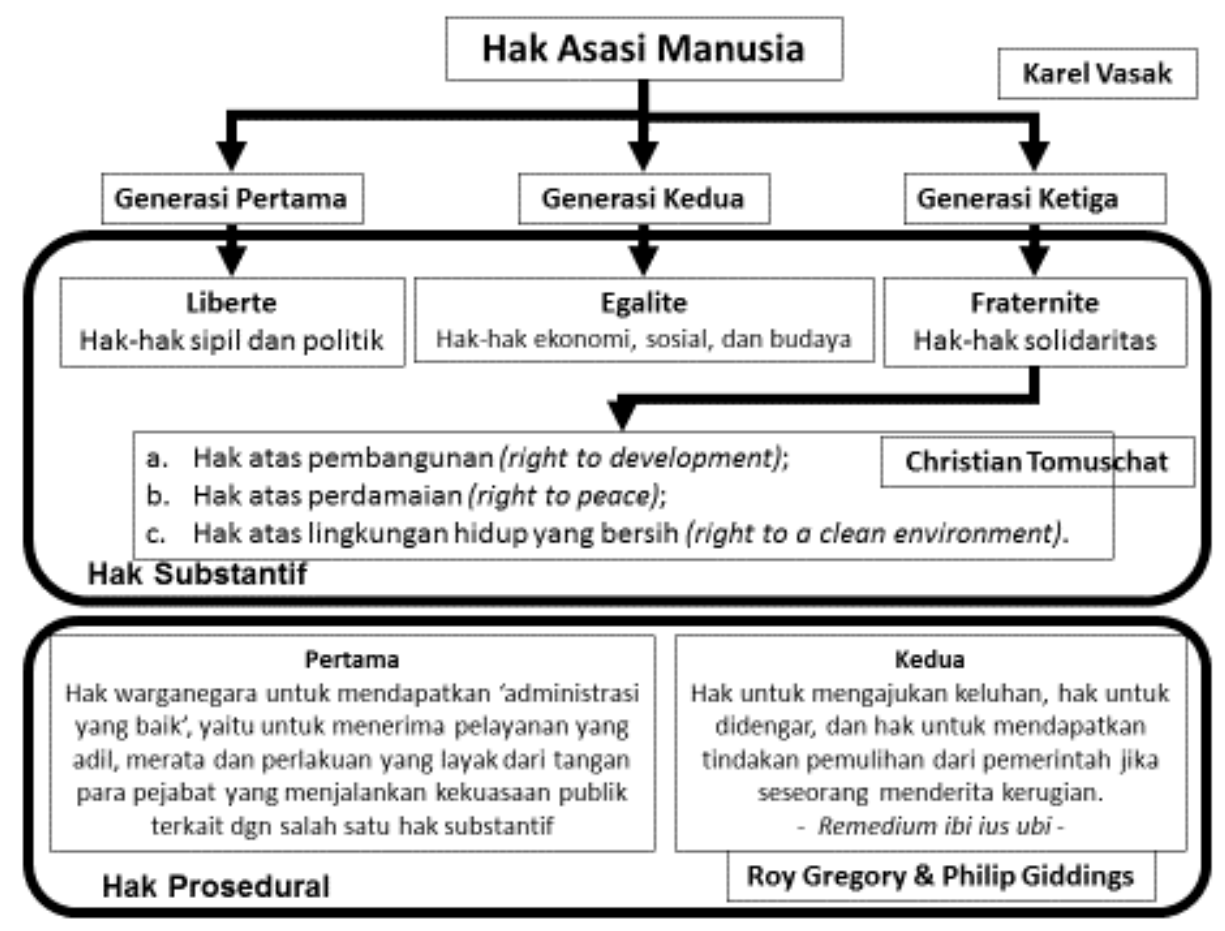

Gambar 2. Generasi Hak Asasi Manusia.

Hak-hak substantif menurut Susi Dwi Harijanti adalah hak-hak yang termasuk dalam hak-hak generasi pertama, kedua, serta ketiga, ${ }^{27}$ sedangkan hakhak prosedural menurut Roy Gregory dan Philip Giddings terdiri atas:

"First, ... right to good administration, that is, to receive fair, just, equitable and considerate treatment at the hands of officials who exercise public power in relation to any of the substantive rights ... and second, ... the right to complain, to be heard, and to have corrective action taken if one has suffered harm from government." 28

Kategori kedua dari - 'hak-hak prosedural' - dibagi menjadi dua: pertama, hak warganegara untuk mendapatkan 'administrasi yang baik', yaitu untuk menerima pelayanan yang adil, merata dan perlakuan yang layak dari tangan para pejabat yang menjalankan kekuasaan publik yang terkait dengan salah satu hak substantif sebagaimana dikemukakan oleh Bradlay dengan menyatakan: "to

\footnotetext{
${ }^{27}$ Susi Dwi Harijanti, 2011, Ombudsman dan The Right to Good Administration, dalam Elly Erawaty, dkk. (editor), Liber Amicorum untuk Prof. Dr. CFG. Sunaryati Hartono, S.H., Penerbit PT. Citra Aditya Bakti, Bandung, hlm. 373.

${ }^{28}$ Roy Gregory dan Philip Giddings, Supra Catatan No.32, hlm. 73.
} 
receive fair just, equitable and considerate treatment at the hands of officials who exercise public power in relation to any of the substantive rights." 29 Kedua, hak untuk mengajukan keluhan, hak untuk didengar, dan hak untuk mendapatkan tindakan pemulihan dari pemerintah jika seseorang menderita kerugian.

Penegasan hak atas lingkungan hidup menemukan momentumnya ketika lahirnya Deklarasi Stockholm pada tanggal 5 Juni 1972. Prinsip pertama deklarasi itu menyatakan: "man has the fundamental right to freedom, equality and adequate conditions of life, in an environment of a quality that permits a life of dignity and well-being." Deklarasi ini semakin memantapkan langkah penghormatan dan perlindungan integritas dari lingkungan global dan sistem pembangunan. Di sini ditegaskan, "human being are the centre of concerns for sustainable development. They are entitled to a healthy and productive life in harmony with nature."

Deklarasi Lingkungan Hidup 1972, selain merupakan lanjutan perjuangan menghormati hak semua makhluk Tuhan, juga merupakan keharusan/tuntutan zaman dan antisipasi lompatan teknologi yang sangat tinggi yang jika tidak hatihati dapat berdampak buruk terhadap lingkungan hidup. Dengan demikian, setelah disepakatinya Deklarasi Lingkungan Hidup tahun 1972 menurut Masyhur Effendi dan Taufani Sukmana Evandri merupakan "Deklarasi Hak-hak Asasi Lingkungan". Dari sisi ini, dituntut setiap pembangunan tidak cukup hanya memerhatikan pilihan teknologi dan mengejar pertumbuhan ekonomi semata, tetapi harus dikaji dan dipertimbangkan juga aspek-aspek lingkungannya. Pembangunan tanpa memperhatikan aspek lingkungan, sama dengan menghancurkan lingkungan dan pada akhirnya menghancurkaan diri manusia sendiri.

Pengangkatan lingkungan hidup dalam posisi sentral memiliki hak, selain bermaksud mengingatkan kita akan pentingnya posisi lingkungan hidup, tumbuhnya kesadaran manusia kepada lingkungan diharapkan semakin

\footnotetext{
${ }^{29}$ Bradley, A.W., The Ombudsman and the Protection of Citizens' Rights, in Gerald E. Caiden (ed.), International Handbook of the Ombudsman: Evolution and Present Function (Westport, Connecticut: Greenwood Press).
} 
meningkat. Budaya menghormati lingkungan menjadi budaya manusia dan cinta lingkungan sebagai sahabat manusia semakin kuat. Selain itu, konsepsi hukum lingkungan, menurut Masyhur Effendi dan Taufani Sukmana Evandri diharapkan akan memperkuat keyakinan pemegang otoritas kekuasaan untuk menjaga lingkungan, di samping tidak salah mengambil keputusan. Dengan demikian, kita dapat mewariskan lingkungan hidup dalam kondisi baik dan sehat kepada anak cucu serta tidak digugat olehnya. ${ }^{30}$ Penempatan lingkungan hidup sebagai subjek hukum semu terinspirasi dari deklarasi tentang lingkungan hidup (Stockholm Declaration) 6 Februari 1972 yang menjadi pegangan bagi anggota PBB. Lewat deklarasi tersebut, berarti ada pengakuan formal atas hak-hak lingkungan. Deklarasi Stockholm 1972 dengan demikian, menurut Munajat Danuseputro merupakan bagian integral dan pelengkap Deklarasi Hak Asasi Manusia 1948. Konferensi tersebut dianggap sebagai "a new liberatic movement to free from the threat of their freedom to environment perils of their own making". ${ }^{31}$

Masyhur Effendi menyatakan bahwa jika kita sepakat mengangkat derajat lingkungan hidup berarti perhatian/komitmen kita kepada lingkungan bukan karena alasan kasihan kepada lingkungan, tetapi lebih ditekankan karena kesadaran. ${ }^{32}$ Masyhur Effendi menyatakan lebih lanjut bahwa lingkungan mempunyai hak, dan hak hidup diberikan kepada lingkungan, karena manusia sadar bahwa tanpa lingkungan yang baik, kehidupan manusia dapat hancur. Untuk itulah, langkah dan keputusan menganggap lingkungan sekitar yang semata-mata sebagai objek untuk memenuhi ambisi/kepuasan maanusia akan merusak lingkungan, karenanya harus dicegah. ${ }^{33}$ Sementara itu, ada pandangan yang lebih maju dengan menempatkan lingkungan hidup tidak sekedar sebagai kwasi subjek hukum/subjek hukum semu dan menurut Masyhur Effendi lingkungan hidup sudah merupakan subjek hukum. Pemikiran ekosentrisme merupakan

30 Masyhur Effendi dan Taufani Sukmana Evandri, HAM Dalam Dimensi/Dinamika Yuridis, Sosial, Politik (Hukum Hak Asasi Manusia) Dalam Masyarakat, Ghalia Indonesia, Bogor, 2007, hlm. 53.

${ }^{31}$ Munajat Danuseputro, 1982, Hukum Lingkungan, Global, Bina Cipta, Bandung, hlm.70.

32 Masyhur Effendi, Prinsip-prinsip Dasar HAM dan Hukum Lingkungan Hidup, FH Universitas Brawijaya, Malang, 1986, hlm. 35.

33 Masyhur Effendi, Id., hlm. 35 
konsekuensi logis akibat perubahan global dari pemikiran yang semula sematamata menekankan anthroposentrisme/homosentrisme. Lewat pandangan ekosentris, maka akan membawa perubahan besar terhadap tata hukum lingkungan internasional dan doktrin manusia sebagai makhluk penguasa satusatunya di bumi yang mempunyai partner sejajar, yaitu alam lingkungan/lingkungan hidup. ${ }^{34}$ Teori ini dikembangkan berdasarkan tesis yang menetapkan lingkungan sebagai subjek hukum, baik sebagai perluasan doktrin hukum lingkungan klasik maupun berdasarkan teori-teori hukum baru yang mendasarkan kepada pendekatan ekologi daripada pendekatan homosentris. Lewat pemikiran tersebut, ajaran ilmu hukum mengalami kemajuan, sekaligus tantangan yang beriringan dengan kemajuan ilmu-ilmu lainnya. Kemajuan tersebut dibarengi dengan langkah-langkah mendasar dan konkret. Adanya peraturan yang jelas/tegas ditambah aparat yang jujur, tegas dalam bertindak, dan memiliki tangan yang kuat (the strong arms) merupakan keharusan hukum. ${ }^{35}$

Deklarasi Rio berawal dari Konferensi PBB tentang Lingkungan dan Pembangunan (the United Nations Conference on Environment and Development) yang dilaksanakan di Rio de Janeiro, Brasil pada tanggal 3-14 Juni 1992. Deklarasi ini berisikan 26 prinsip yang mendasari perlindungan dan pemenuhan HAM atas lingkungan yang sehat dan bersih. Mukaddimah The Rio Declaration on Environment and Development menegaskan bahwa the integral and interdependent nature of the earth, our home. Penegasan ini mencerminkan sikap universalitas kehidupan manusia. Pernyataan ini sekaligus menegaskan posisi sentral dari dua hubungan yang aktif antara manusia dan alam lingkungan hidupnya. Alam merupakan wahana lingkungan hidup bagi manusia. Ia dapat bertahan sebagai sumber kehidupan ketika alam dirawat, dijaga dan dilestarikan. Maka, jika alam rusak, kehidupan manusia juga akan rusak. Tidak hanya itu, kerusakan alam merupakan bukti kebodohan yang paling fundamental karena mewariskan kerusakan serupa pada generasi-generasi selanjutnya. Driyarkara menyatakan

\footnotetext{
34 Masyhur Effendi dan Taufani Sukmana Evandri, Supra Catatan No. 31, hlm. 54-55.

35 Masyhur Effendi dan Taufani Sukmana Evandri, Id, hlm. 55.
} 
bahwa manusia itu dengan alamnya atau dunianya merupakan satu konstruksi. Karena konstruksi ini, maka manusia hanya bisa berkembang sebagai manusia dengan memperkembangkan alam. Dia harus membangun kebudayaan dengan bermacam bentuknya dan hanya dengan hidup dalam pembangunannya itu manusia berkembang sebagai manusia. ${ }^{36}$

Deklarasi Stockholm dan Deklarasi Rio menurut Majda El Muhtaj mengafirmasi pentingnya penghormatan dan perlindungan terhadap HAM atas lingkungan hidup. Ada satu konsensus yang penting dari pertemuan di Rio de Janeiro, Brasil, yakni kesadaran jamak untuk mampu mewariskan bumi yang lestari bagi generasi mendatang. ${ }^{37} \mathrm{Hal}$ itu berarti pemerintahan di seluruh dunia memiliki kewajiban untuk komitmen pada terjaminnya pemenuhan HAM atas lingkungan hidup yang sehat dan bersih (right to clean and healthy environment). Hal ini terlihat jelas dari Prinsip Keempat Deklarasi Rio yang menegaskan: "in order to achieve sustainable development, environmental protection shall constitute an integral part of the development process and cannot be considered in isolation from it." Senada dengan itu, masyarakat internasional juga telah menuangkan gagasan pentingnya kesadaran lingkungan. Pada September tahun 2000, 147 (seratus empat puluh tujuh) negara dari 190 (seratus sembilan puluh) negara peserta PBB waktu itu telah menetapkan salah satu poin terpenting dalam Millennium Development Goals (MDGs) adalah ensure environmental sustainability, artinya bahwa kesadaran lingkungan bukan lagi normativitas lokal saja, melainkan sebuah konstruk kehidupan bersama. Kesadaran lingkungan yang baik telah menjadi wacana global yang penting dan amat mendesak.

\footnotetext{
36 Driyarkara, Karya Lengkap Driyarkara: Esai-Esai Filsafat Pemikir yang Terlibat Penuh dalam Perjuangan Bangsanya, PT. Gramedia Pustaka Utama, Jakarta, 2006, hlm. 943.

37 Majda El Muhtaj, Supra Catatan No.26.
} 


\section{Konstitusi Hijau (Green Constitution)}

Ketentuan mengenai lingkungan hidup dirumuskan dalam Pasal 28H ayat (1) dan Pasal 33 ayat (4) UUD 1945. Pasal 28H ayat (1) UUD 1945 jelas menyatakan:

"Setiap orang berhak hidup sejahtera lahir dan batin, bertempat tinggal, dan mendapatkan lingkungan hidup yang baik dan sehat serta berhak memperoleh pelayanan kesehatan."

Hak untuk memperoleh lingkungan hidup yang baik dan sehat serta pelayanan kesehatan yang baik, merupakan hak asasi manusia. Karena itu, UUD 1945 jelas sangat pro-lingkungan hidup, sehingga dapat disebut sebagai konstitusi hijau (green constitution).

Sebagai imbangan adanya hak asasi setiap orang itu berarti negara diharuskan untuk menjamin terpenuhinya hak setiap orang untuk memperoleh lingkungan hidup yang baik dan sehat yang termasuk kategori hak asasi manusia tersebut. Sebagai hak setiap orang, tentunya secara bertimbal-balik pula mewajibkan semua orang untuk menghormati hak orang lain sehubungan dengan lingkungan yang baik dan sehat itu. Oleh karena itu, di satu segi setiap orang berhak atas lingkungan hidup yang baik dan sehat, tetapi di pihak lain setiap orang juga berkewajiban untuk menjaga dan menghormati hak orang lain untuk mendapatkan dan menikmati lingkungan hidup yang baik dan sehat itu. Demikian pula negara, disamping dibebani kewajiban dan tanggung jawab untuk menjamin lingkungan hidup yang baik dan sehat, juga berhak menuntut setiap orang untuk menghormati hak orang lain, dan apabila perlu memaksakan setiap orang untuk tidak merusak dan mencemarkan lingkungan hidup untuk kepentingan bersama.

Dengan ketentuan Pasal 28H ayat (1) UUD 1945, berarti norma lingkungan hidup telah mengalami konstitusionalisasi menjadi materi muatan konstitusi sebagai hukum tertinggi. Dengan demikian, segala kebijakan dan tindakan pemerintahan dan pembangunan haruslah tunduk kepada ketentuan mengenai hak asasi manusia atas lingkungan hidup yang baik dan sehat. Tidak boleh ada lagi kebijakan yang tertuang dalam bentuk undang-undang ataupun peraturan di 
bawah undang-undang yang bertentangan dengan ketentuan konstitusional yang pro-lingkungan ini.

Perkembangan kebijakan lingkungan hidup menurut Jimly Asshiddiqie terdiri dari 2 (dua) tahap perkembangan lingkungan hidup. ${ }^{38}$ Pada tahap pertama, atas dorongan kesadaran yang semakin luas di seluruh dunia mengenai pentingnya upaya melindungi lingkungan dari ancaman pencemaran dan perusakan, kebijakan lingkungan hidup dituangkan dalam bentuk peraturan perundang-undangan secara resmi. Dengan demikian, timbul gelombang dunia, yaitu gelombang legalisasi atau legislasi kebijakan lingkungan hidup. Setelah ditetapkan begitu banyak peraturan perundang-undangan secara resmi, ternyata kebanyakan peraturan-peraturan itu tidak efektif untuk mencegah terjadinya pencemaran dan perusakan lingkungan hidup. Ketidakpuasan demikian berkembang luas di banyak negara, sehingga muncul tuntutan untuk memperkuat payung hukum kebijakan lingkungan hidup itu dalam konstitusi sebagai hukum yang tertinggi. Perkembangan terakhir inilah yang Jimly Asshiddiqie namakan sebagai gelombang kedua atau perkembangan tahap kedua dengan melakukan konstitusionalisasi kebijakan lingkungan itu ke dalam rumusan UUD 1945.

Seperti dikemukakan di atas, pada Gelombang Pertama, kebijakan lingkungan hidup diformulasikan dalam peraturan perundang-undangan negara secara resmi. Agar memiliki kedudukan yang tinggi dengan daya paksa yang mengikat untuk umum, kebijakan lingkungan dan ide pembangunan berkelanjutan dituangkan dalam undang-undang yang dibuat oleh lembaga parlemen dan pemerintah (legislative acts). Gejala demikian ini berkembang sejak tahun 1970-an dan berpengaruh di Indonesia pada akhir tahun 1970-an. Karena itu, pada era 1980-an, berkembang tuntutan yang meluas agar kebijakankebijakan resmi pemerintah Indonesia yang pro-lingkungan dapat tercermin

38 Jimly Asshiddiqie, Green Constitution: Nuasa Hijau Undang-Undang Dasar Negara Republik Indonesia Tahun 1945, PT. RajaGrafindo Persada, Jakarta, 2009, hlm. 159. 
dalam bentuk perundang-undangan yang mengikat untuk ditaati oleh semua pemangku kepentingan (stakeholders). 39

Persoalan lingkungan seringkali dianggap hanya sebagai salah satu sektor yang penting, tetapi sektor-sektor lain yang penentuan kebijakannya tidak berada di wilayah tanggung jawab Menteri Lingkungan Hidup juga harus dianggap penting. Dalam pertarungan antarsektor dan antarinstansi ini, kepentingan lingkungan hidup dalam praktik, selalu kalah atau dikalahkan oleh bidang, sektor, atau kebijakan-kebijakan instansi-instansi lain, seperti bidang-bidang pertambangan dan energi, kehutanan dan perkebunan, investasi, pariwisata, dan lain-lain sebagainya.

Kalahnya kepentingan lingkungan hidup dalam pertarungan yang tidak seimbang melawan kepentingan-kepentingan lain terjadi tidak hanya di forumforum yang teknis eksekutif, tetapi juga di forum-forum politik, di lingkungan lembaga legislatif. Oleh kerena itu, di samping ada undang-undang di bidang lingkungan hidup yang tentu saja berpihak kepada lingkungan hidup, banyak pula produk undang-undang di bidang-bidang lain yang justru tidak ramah lingkungan. Hal demikian tentu harus diterima sebagai kenyataan yang ada di lingkungan lembaga perwakilan rakyat yang menjadi muara dari semua jenis kepentingan yang hidup dan saling bertarung dalam masyarakat.

Keputusan-keputusan di forum-forum politik semacam ini tentu saja yang berlaku adalah prinsip majoritarian, yaitu siapa yang paling banyak jumlahnya yang menentukan keputusan. Karena itu, yang lebih utama dalam pengambilan keputusan demokratis di forum parlemen adalah kuantitas pendukung, bukan kualitas ide yang perlu didukung. Oleh karena pendukung ide-ide lingkungan hidup ini jumlahnya jauh lebih sedikit dan jauh dari posisi politik yang menentukan, maka ketika menghadapi beraneka ragam kepentingan lain yang juga rasional, maka kadangkala kebijakan yang pro lingkungan hidup menjadi kalah suara.

${ }^{39}$ Jimly Asshiddiqie, Id. 
Karena itu, muncul pemikiran untuk menaikkan derajat norma perlindungan lingkungan hidup ke tingkat Undang-Undang Dasar. Dengan kata lain, berkembang ide untuk mengadopsikan norma-norma hukum lingkungan itu ke dalam rumusan pasal-pasal Undang-Undang Dasar sehingga kedudukannya lebih kuat. Dengan dicantumkan dalam Undang-Undang Dasar, setiap produk undang-undang yang dibuat oleh lembaga parlemen dapat dikontrol karena harus tunduk kepada norma konstitusi. Forum parlemen yang biasanya harus mengkompromikan pelbagai kepentingan yang saling bertentangan yang mencerminkan kehidupan masyarakat yang diwakili oleh para wakil rakyat itu, harus menundukkan diri pada konstitusi sebagai hukum tertinggi. Gelombang kesadaran untuk menuangkan norma hukum lingkungan ke dalam teks UndangUndang Dasar inilah yang Jimly Asshiddiqie namakan dengan gejala konstitusionalisasi (constitutionalization of environmental policy) yang merupakan Gelombang Kedua dalam perkembangan kebijakan lingkungan hidup.

Di Indonesia, hak atas lingkungan telah diadopsi dalam berbagai peraturan perundang-undangan, baik konstitusi negara pascaamandemen maupun undangundang. Dalam Pasal 28H ayat (1) UUD 1945 menyatakan:

"Setiap orang berhak hidup sejahtera lahir dan batin, bertempat tinggal dan mendapat lingkungan hidup yang baik dan sehat, berhak memperoleh pelayanan kesehatan."

Dan diatur lebih lanjut dalam Pasal 65 ayat (1) Undang-Undang Nomor 32 Tahun 2009 tentang Perlindungan dan Pengelolaan Lingkungan Hidup (selanjutnya disebut UU Nomor 32 Tahun 2009), yang menyatakan:

"Setiap orang mempunyai hak yang sama atas lingkungan hidup yang baik dan sehat."

Kemudian dalam Pasal 65 ayat (2) UU Nomor 32 Tahun 2009 menyatakan:

"Setiap orang berhak mendapat ... akses keadilan dalam memenuhi hak atas lingkungan hidup yang baik dan sehat." 
Dalam ketentuan Pasal 33 ayat (4) UUD 1945 yang menyatakan:

"Perekonomian nasional diselenggarakan berdasarkan atas demokrasi ekonomi dengan prinsip kebersamaan, efisiensiberkeadilan, berkelanjutan, berwawasan lingkungan, kemandirian, serta dengan menjaga keseimbangan kemajuan dan kesatuan ekonomi nasional."

Terdapat dua konsep yang berkaitan dengan ide tentang ekosistem, yaitu bahwa perekonomian nasional berdasarkan atas demokrasi ekonomi dimaksud haruslah mengandung prinsip berkelanjutan dan berwawasan lingkungan. Dengan sendirinya menurut Jimly Asshiddiqie keseluruhan ekosistem seperti yang dimaksud dalam Pasal 33 ayat (3) UUD 1945 sebagaimana ditafsirkan secara ekstensif dan kreatif oleh pelbagai undang-undang di bidang lingkungan hidup, haruslah dikelola untuk kepentingan pembangunan berdasarkan prinsip pembangunan berkelanjutan (sustainable development) dan wawasan lingkungan (pro-environment) sebagaimana ditentukan oleh Pasal 33 ayat (4) UUD 1945.

Oleh karena itu, cukup alasan untuk menyebut bahwa UUD 1945 pascareformasi atau sesudah Perubahan Keempat pada 10 Agustus 2002 juga sudah berwarna hijau atau green constitution. ${ }^{40}$ Di tengah semakin berkembangnya iklim demokrasi di berbagai negara, termasuk di Indonesia, isu keadilan lingkungan menurut Sonny Keraf telah menjelma dari sebuah gagasan yang terkesan abstrak menuju sesuatu yang memang harus dan dapat diperjuangkan bahkan seringkali keadilan memang harus direbut. ${ }^{41}$

Berdasarkan uraian di atas maka dengan ketentuan Pasal 28H ayat (1) dan Pasal 33 ayat (1) UUD 1945, berarti norma lingkungan hidup telah mengalami konstitusionalisasi menjadi materi muatan konstitusi sebagai hukum tertinggi (green constitution).

Dengan demikian, segala kebijakan dan tindakan pemerintahan dan pembangunan haruslah tunduk kepada ketentuan mengenai hak asasi manusia

\footnotetext{
${ }^{40}$ Jimly Asshiddiqie, Id, hlm. 182.

41 Sonny Keraf, Etika Lingkungan Hidup, Buku Kompas, Jakarta, 2010.
} 
atas lingkungan hidup yang baik dan sehat. Tidak boleh ada lagi kebijakan yang tertuang dalam bentuk undang-undang ataupun peraturan di bawah undangundang yang bertentangan dengan ketentuan konstitusional yang pro-lingkungan ini (green legislation) atau dengan perkataan lain kebijakan yang bernuansa lingkungan hidup atau hijau harus tercermin dalam setiap peraturan perundangundangan (green legislation) sebagaimana diamanatkan dalam Pasal 44 UU Nomor 32 Tahun 2009 yang berbunyi:

"Setiap penyusunan peraturan perundang-undangan pada tingkat nasional dan daerah wajib memerhatikan perlindungan fungsi lingkungan hidup dan prinsip perlindungan dan pengelolaan lingkungan hidup sesuai dengan ketentuan yang diatur dalam UndangUndang ini."

Peraturan perundang-undangan berbasis lingkungan hidup (green legislation) tentu saja diperkuat dengan norma lingkungan hidup yang terkonstitusionalisasikan dalam UUD 1945 (green constitution) sebagaimana diamanatkan dalam Pasal 28H dan Pasal 33 ayat (4) UUD 1945.

Tuntutan reformasi pada tahun 1998 dengan salah satu agendanya yaitu amandemen sampai kepada perubahan ke-4 UUD 1945, menghasilkan banyak rumusan pasal-pasal baru terutama terkait dengan Hak Asasi Manusia. Isu lingkungan pun akhirnya menjadi salah satu Hak Asasi Manusia yang tercantum dalam Pasal 28H ayat (1) UUD 1945 yang menegaskan:

Setiap orang berhak hidup sejahtera lahir dan batin, bertempat tinggal, dan mendapatkan lingkungan hidup yang baik dan sehat serta berhak memperoleh pelayanan kesehatan."

Hal tersebut tentu memberikan dampak positif yang secara tidak langsung negara berkewajiban untuk betul-betul melestarikan lingkungan hidup yang baik dan sehat untuk memenuhi hak warga negaranya. Selain Pasal 28H ayat (1) UUD 1945, dalam Pasal 33 ayat (1) UUD 1945 menegaskan pula:

"Perekonomian disusun sebagai usaha bersama berdasar atas asas kekeluargaan." 
Ditambahkan pula dalam ketentuan Pasal 33 ayat (4) UUD 1945 yang menyatakan:

"Perekonomian nasional diselenggarakan berdasar atas demokrasi ekonomi dengan prinsip kebersamaan, efisiensi berkeadilan, berkelanjutan, berwawasan lingkungan, kemandirian, serta dengan menjaga keseimbangan kemajuan dan kesatuan ekonomi nasional". 42

Berdasarkan pada ketiga pasal tersebut, Indonesia sebenarnya telah menerapkan konsep ecocracy yaitu kedaulatan lingkungan hidup atau ekosistem di mana suatu pemerintahan mendasarkan kepemerintahannya secara taat asas pada prinsip-prinsip pembangunan berkelanjutan yang berwawasan lingkungan (ecologically sustainable development). Gagasan ecocracy ini merupakan upaya untuk mengutamakan pembangunan berkelanjutan yang berwawasan lingkungan hidup dalam arus politik pembangunan nasional. Namun, walaupun Indonesia dalam konstitusinya telah mengakui subjective right atau duty of the state tetapi pemuatan pola dan arah pembangunan berkelanjutan belum ditempatkan pada pasal-pasal khusus melainkan ditumpangkan atau dicampurkan dengan hak-hak fundamental lainnya. Oleh karena itu, dengan teori hierarki peraturan perundangundangan sesuai dengan Undang-Undang Nomor 12 Tahun 2011 tentang Pembentukan Peraturan Perundang-undangan, Pemerintah Indonesia wajib menyesuaikan seluruh peraturan perundang-undangan di Indonesia agar menjadi peraturan yang berkelanjutan dan berwawasan lingkungan. Tata urutan peraturan perundang-undangan sebagaimana diamanatkan dalam Pasal 7 Undang-Undang Nomor 12 Tahun 2011 tentang Pembentukan Peraturan Perundang-undangan, yaitu terdiri atas:

1. Undang-Undang Dasar 1945;

2. Ketetapan Majelis Permusyawaratan Rakyat;

3. Undang-Undang/Peraturan Pemerintah Pengganti Undang-Undang;

4. Peraturan Pemerintah;

5. Peraturan Presiden;

42 Perubahan Keempat Undang-Undang Dasar Negara Republik Indonesia Tahun 1945, ditetapkan 10 Agustus 2002. 
6. Peraturan Daerah Provinsi;

7. Peraturan Daerah Kabupaten/Kota.

DPR dan Pemerintah pada tanggal 8 september 2009 mengesahkan Undang-Undang Nomor 32 Tahun 2009 tentang Perlindungan dan Pengelolaan Lingkungan Hidup (UU Nomor 32 Tahun 2009) sebagai pengganti Undang-Undang Nomor 23 Tahun 1997 tentang Pengelolaan Lingkungan Hidup (UU Nomor 23 Tahun 1997). Terhadap UU Nomor 23 Tahun 1997 ini tentunya banyak perubahan. Dari segi judulnya, jelas sudah berubah dengan ditambahkannya klausul kata perlindungan selain kata pengelolaan. Dalam pengelolaan lingkungan hidup untuk mencegah kerusakan lahan perlu dilakukan penegakkan peraturan perundangan-undangan untuk melindungi lingkungan hidup itu sendiri.

Sesuai dengan teori hierarki peraturan perundang-undangan, maka dalam membuat peraturan perundang-undangan harus sesuai dengan peraturan di atasnya dan tidak boleh bertentangan dengan peraturan di atasnya. UU Nomor 32 Tahun 2009 tentunya masih banyak penyesuaian yang harus dilakukan. Dalam pelaksanaan teknis UU Nomor 32 Tahun 2009 dalam peraturan pemerintah dan peraturan presiden hendaknya juga disesuaikan dengan UU Nomor 32 Tahun 2009 agar tidak terjadi benturan hukum karena masih mengacu pada UU Nomor 23 Tahun 1997. Hal ini juga diatur pula dalam Pasal 44 UU Nomor 32 Tahun 2009 bahwa setiap penyusunan peraturan perundang-undangan pada tingkat nasional dan daerah wajib memperhatikan perlindungan fungsi lingkungan hidup dan prinsip perlindungan dan pengelolaan lingkungan hidup sesuai dengan ketentuan yang diatur dalam UU Nomor 32 Tahun 2009.

Peraturan Perundang-undangan berbasis lingkungan hidup (Green Legislation)

Indonesia sebagai negara yang mendasarkan pada Pancasila dan Undang-Undang Dasar Negara Republik Indonesia Tahun 1945 (UUD 1945), segala aspek kehidupan dalam bidang kemasyarakatan, kebangsaan, dan kenegaraan termasuk 
pemerintahan harus senantiasa berdasarkan atas hukum. Untuk mewujudkan negara hukum tersebut pada tanggal 12 Agustus 2011 diundangkanlah UndangUndang Nomor 12 Tahun 2011 tentang Pembentukan Peraturan Perundangundangan (UU Nomor 12 Tahun 2011) pengganti Undang-Undang Nomor 10 Tahun 2004 tentang Pembentukan Peraturan Perundang-undangan (UU Nomor 10 Tahun 2004) yang diperlukan sebagai tatanan yang tertib di bidang pembentukan peraturan perundang-undangan. Untuk membentuk peraturan perundang-undangan yang baik, diperlukan berbagai persyaratan yang berkaitan dengan sistem, asas, tata cara penyiapan dan pembahasan, teknik, penyusunan maupun pemberlakuannya sebagaimana dijelaskan dalam Penjelasan Umum UU Nomor 12 Tahun 2011. Dengan perkataan lain, dalam penyusunan peraturan perundang-undangan harus berdasarkan pada konsep atau norma dasar (good norms) dan sekaligus dalam rangka memberikan pengayaan dan penyamaan pemahaman tentang apa yang perlu dilakukan dan bagaimana proses dilakukan dalam penyusunan suatu peraturan perundang-undangan tersebut (good process).

Pengertian peraturan perundang-undangan terdapat dalam Pasal 1 angka UU Nomor 12 Tahun 2011 yang menyatakan: "Peraturan perundang-undangan adalah peraturan tertulis yang memuat norma hukum yang mengikat secara umum dan dibentuk atau ditetapkan oleh lembaga negara atau pejabat yang berwenang melalui prosedur yang ditetapkan dalam Peraturan Perundangperundangan. Berdasarkan Ketentuan tersebut dapat diketahui bahwa unsurunsur yang membentuk peraturan perundang-undangan yang meliputi 3 (tiga) hal, yaitu:

a. peraturan tertulis;

b. dibentuk oleh lembaga negara atau pejabat yang berwenang;

c. mengikat secara umum.

Unsur pertama menyangkut bentuk produk hukum yang dikatakan sebagai peraturan perundang-undangan. Produk hukum dapat dibuat secara lisan, tetapi ada pula yang dibuat secara tertulis. Dalam kaitan dengan hal ini, semua produk 
hukum yang dikategorikan sebagai peraturan perundang-undangan mesti dalam bentuk tertulis. Dengan kata lain, tidak dikenal adanya produk hukum berupa peraturan perundang-undangan dalam bentuk keputusan lisan.

Unsur kedua menyangkut subjek yang membentuk suatu produk hukum yang dinamakan sebagai peraturan perundang-undangan itu, mestilah lembaga negara atau pejabat yang berwenang. Dalam kaitan dengan ini, kewenangan menjadi begitu penting, hanya lembaga negara yang diberikan kewenangan atau mempunyai kewenangan dalam pembuatan produk hukum yang dimaksud saja yang dapat membuat peraturan perundang-undangan. Dengan demikian pula apa yang dimaksud dalam Pasal 1 angka 2 UU Nomor 12 Tahun 2011 yaitu peraturan tertulis dalam bentuk statutory law atau statutory legislations, disebut pula legislative acts, yaitu kewenangan untuk mengatur atau membuat aturan (regeling) pada dasarnya merupakan domain kewenangan lembaga legislatif yang berdasarkan prinsip kedaulatan merupakan kewenangaan eksklusif para wakil rakyat yang berdaulat untuk menentukan sesuatu peraturan yang mengikat dan membatasi kebebasan setiap individu warga negara (presumption of liberty of the souvereign people). Dalam proses pembentukan legislative acts, peranan lembaga legislatif sangat menentukan keabsahan materiel peraturan yang dimaksud. Dengan peranan lembaga legislatif yang sangat menentukan itu berarti peranan para wakil rakyat yang dipilih dan mewakili kepentingan rakyat yang berdaulat dari mana kedaulatan negara berasal sangat menentukan keabsahan dan daya ikat peraturan perundang-undangan itu untuk umum.

Unsur ketiga, bahwa produk hukum itu mesti ditujukan kepada umum. Dalam hal ini bukan ditujukan kepada individu atau dalam bidang hukum sering kali digunakan istilah "bersifat mengatur". Hal ini memang tepat karena produk hukumnya saja sudah disebut sebagai peraturan perundang-undangan maka tentu juga dituujukan kepada publik, khalayak, atau kepada masyarakat, bukan kepada pribadi tertentu. Peraturan tertulis yang bersifat umum (algemenen verbindende voorschiften) berisi norma hukum yang menurut Hans Kelsen bersifat umum dan 
abstrak (general and abstract norms). Norma-norma hukum yang bersifat mengatur (regeling) dengan isi norma yang bersifat umum dan abstrak (general and abstract norms) itu dituangkan dalam bentuk tertulis tertentu yang disebut sebagai peraturan perundang-undangan. Disebut peraturan (regels) karena produk hukum tersebut memang merupakan hasil atau outcome dari suatu rangkaian aktivitas pengaturan (regeling).

Untuk membentuk peraturan perundang-undangan yang baik sebagaimana ditentukan dalam UU Nomor 12 Tahun 2011, diperlukan berbagai persyaratan yang berkaitan dengan sistem, asas, tata cara penyiapan dan pembahasan, teknik, penyusunan maupun pemberlakuannya. Persyaratan yang berkaitan asas, UU Nomor 12 Tahun 2004 yang mengatur mengenai asas-asas pembentukan peraturan perundang-undangan, asas-asas materi muatan peraturan perundangundangan dan asas-asas lain sesuai dengan bidang hukum peraturan perundangundangan yang diaturnya.

Asas-asas Pembentukan Peraturan Perundang-undangan (algemene beginselen van behoorlijk wetgeving) dalam UU Nomor 12 Tahun 2011 diatur dalam Pasal 5 yang menyatakan bahwa dalam membentuk Peraturan Perundangundangan harus berdasarkan pada asas Pembentukan Peraturan Perundangundangan yang baik meliputi: kejelasan tujuan, kelembagaan atau organ pembentuk yang tepat, kesesuaian antara jenis, hierarki dan materi muatan, dapat dilaksanakan kedayagunaan dan kehasilgunaan, kejelasan rumusan, keterbukaan.

Pembentukan Peraturan Perundang-undangan selain harus berdasarkan asas-asas pembentukan peraturan perundang-undangan berdasarkan Pasal 6 ayat (1) UU Nomor 12 Tahun 2011 juga harus memuat asas-asas materi muatan peraturan perundang-undangan: pengayoman, kemanusiaan, kebangsaan, kekeluargaan, kenusantaraan, bhineka tunggal ika, keadilan, kesamaan kedudukan dalam hukum dan pemerintahan, ketertiban, kepastian hukum, dan/atau keseimbangan, keserasian, dan keselarasan. 
Selain asas-asas pembentukan peraturan perundang-undangan dan asas materi muatan peraturan perundang-undangan, Pasal 6 ayat (2) UU Nomor 12 Tahun 2011 menyatakan bahwa selain asas-asas materi muatan peraturan perundang-undangan, Peraturan Perundang-undangan tertentu dapat berisi asas lain sesuai dengan bidang hukum Peraturan Perundang-undangan yang bersangkutan.

Berkaitan dengan perlindungan dan pengelolaan lingkungan hidup dengan diundangkannya UU Nomor 32 Tahun 2009, maka dalam pembentukan peraturan perundang-undangan yang berkaitan dengan perlindungan dan pengelolaan baik di pusat maupun daerah selain harus memenuhi asas-asas pembentukan peraturan perundangan-undangan sebagaimana diatur dalam Pasal 5 UU Nomor 12 Tahun 2011 dan asas-asas materi muatan peraturan perundang-undangan sebagaimana diatur dalam Pasal 6 ayat (2) UU Nomor 12 Tahun 2011 harus pula memenuhi asas-asas sebagaimana ditentukan dalam UU Nomor 32 Tahun 2009 yaitu prinsip atau asas perlindungan dan pengelolaan lingkungan hidup sebagaimana diatur dalam Pasal 2 UU Nomor 32 Tahun 2009 yang menyatakan bahwa perlindungan dan pengelolaan lingkungan hidup dilaksanakan berdasarkan asas: tanggung jawab negara, kelestarian dan keberlanjutan, keserasian dan keseimbangan, keterpaduan, manfaat, kehati-hatian, keadilan, ekoregion, keanekaragaman hayati, pencemar membayar, partisipatif, kearifan lokal, tata kelola pemerintahan yang baik; dan otonomi daerah.

Namun UU Nomor 32 Tahun 2009 mengamanatkan pula bahwa setiap penyusunan atau pembentukan peraturan perundang-undangan baik pada tingkat nasional maupun daerah wajib memperhatikan 2 (dua) hal yaitu (1) perlindungan fungsi lingkungan hidup dan (2) prinsip perlindungan dan pengelolaan lingkungan hidup sebagaimana diatur dalam Pasal 44 yang menyatakan: "Setiap penyusunan peraturan perundang-undangan pada tingkat nasional dan daerah wajib memperhatikan perlindungan fungsi lingkungan hidup dan prinsip perlindungan dan pengelolaan lingkungan hidup sesuai dengan ketentuan yang diatur dalam 
Undang-Undang ini.” Berdasarkan ketentuan Pasal 44 UU Nomor 32 Tahun 2009 mengamanatkan penuangan kebijakan lingkungan (green policy) ke dalam setiap peraturan perundang-undangan yang tidak hanya dalam peraturan perundangundangan yang terkait dengan perlindungan dan pengelolaan lingkungan hidup tetapi juga terhadap semua peraturan perundang-undangan. Penuangan kebijakan lingkungan (green policy) ke dalam setiap peraturan perundang-undangan biasa diterjemahkan ke dalam bahasa Inggris dengan green legislation, atau dapat diterjemahkan dengan peraturan perundang-undangan hijau. Peraturan Perundang-undangan hijau (green legislation) berdasarkan Pasal 44 UU Nomor 32 Tahun 2009 wajib memperhatikan 2 (dua) hal yaitu (1) perlindungan fungsi lingkungan hidup dan (2) prinsip perlindungan dan pengelolaan lingkungan hidup sebagaimana telah dijelaskan di atas.

\section{Anggaran Berbasis Lingkungan Hidup (Green Budgeting)}

Konsep Green Budgeting muncul pada era akhir 1990-an selaras dengan berkembangnya konsep sustainable development. Green budgeting adalah suatu gagasan praktis tentang penerapan sustainable development dalam sistem anggaran, yang terintegrasi dalam suatu dokumen kebijakan yang didasarkan pada prinsip sustainability. Dalam hal ini, walaupun green budgeting merupakan bagian dari kebijakan ekonomi, tetapi dalam penerapannya green budgeting juga akan menimbulkan dampak kebijakan yang sifatnya non-economical.

Konsep Green Budgeting ini merupakan hal yang relatif baru di Indonesia dan dapat dianggap pula sebagai paradigma. Green Budgeting menurut Wilkinson dimaknai sebagai paradigma penganggaran yang memprioritaskan unsur kelestarian lingkungan dalam penyusunan, implementasi, pengawasan sampai evaluasi dalam belanja pemerintah dan juga pendapatan yang mendukungnya. Simplifikasinya, apapun yang ada di belanja dan pendapatan pemerintah diupayakan untuk memenuhi prinsip kelestarian lingkungan. Konsep Green Budgeting telah diadopsi oleh UU Nomor 32 Tahun 2009 sebagaimana diatur 
dalam Pasal 45 dan Pasal 46. Pasal 45 UU Nomor 32 Tahun 2009 mengamanatkan:

(1) Pemerintah dan Dewan Perwakilan Rakyat Republik Indonesia serta pemerintah daerah dan Dewan Perwakilan Rakyat Daerah wajib mengalokasikan anggaran yang memadai untuk membiayai:

a. kegiatan perlindungan dan pengelolaan lingkungan hidup; dan

b. program pembangunan yang berwawasan lingkungan hidup.

(2) Pemerintah wajib mengalokasikan anggaran dana alokasi khusus lingkungan hidup yang memadai untuk diberikan kepada daerah yang memiliki kinerja perlindungan dan pengelolaan lingkungan hidup yang baik.

Alokasi anggaran yang memadai untuk membiayai kegiatan perlindungan dan pengelolaan lingkungan hidup dan program pembangunan yang berwawasan lingkungan hidup sebagaimana diamanatkan dalam Pasal 45 ayat (1) UU Nomor 32 Tahun 2009 tersebut berbeda dengan Undang-Undang Nomor 20 Tahun 2003 tentang Sistem Pendidikan Nasional (UU Nomor 20 Tahun 2003) dan UndangUndang Nomor 36 Tahun 2009 tentang Kesehatan (UU Nomor 36 Tahun 2009). UU Nomor 20 Tahun 2003 dalam Pasal 49 ayat (1) mengamanatkan besar anggaran dialokasikan minimal 20\% dari APBN dan minimal 20\% dari APBD. Sedangkan UU Nomor 36 Tahun 2009 dalam Pasal 171 mengamanatkan besar anggaran kesehatan Pemerintah dialokasikan minimal sebesar 5\% (lima persen) dari APBN di luar gaji dan anggaran kesehatan pemerintah daeah provinsi, kabupaten/kota dialokasikan minimal 10\% (sepuluh persen) dari APBD di luar gaji. UU Nomor 32 Tahun 2009 mengalokasikan anggaran yang memadai tidak menyebutkan besaran, di mana perlu ditentukan ukuran atau kriteria memadai tersebut dan penggunaan anggaran tersebut. Alokasi anggaran yang memadai dapat didasarkan pada ukuran atau kriteria: ${ }^{43}$

a. jumlah penduduk;

43 Asep Warlan Yusuf, dalam rangka Konsultasi Pemerintah Provinsi Kepulauan Riau kepada Kementerian Lingkungan Hidup terkait Penyusunan Peraturan Daerah tentang Perlindungan dan Pengelolaan Lingkungan Hidup, khususnya terkait Anggaran Berbasis Lingkungan Hidup (Green Budgeting), tertanggal 18 Agustus 2014. 
b. kompleksitas dan kegiatan masyarakat yang berdampak pada lingkungan;

c. efek atau pengaruh dari pencemaran dan/atau kerusakan terhadap kesehatan dan keselamatan warga;

d. daya pulih sebagai akibat dari pencemaran dan/atau kerusakan;

e. masih rendahnya kesadaran hukum masyarakat terhadap lingkungan hidup.

Alokasi anggaran yang memadai dalam kegiatan perlindungan dan pengelolaan lingkungan hidup dan program pembangunan yang berwawasan lingkungan hidup tersebut dapat digunakan untuk:44

a. penyusunan RPPLH;

b. penyusunan KLHS;

c. perizinan;

d. pengawasan;

e. peningkatan kapasitas PPLHD/PPNS;

f. pemberdayaan masyarakat; dan

g. pengembangan dan sosialisasi peraturan perundang-undangan dan kebijakan di bidang lingkungan hidup;

h. penegakan hukum; dan/atau

i. kegiatan dan program lainnya dalam rangka perlindungan dan pengelolaan lingkungan hidup dan program pembangunan yang berwawasan lingkungan hidup.

Kriteria kinerja perlindungan dan pengelolaan lingkungan hidup sebagaimana diamanatkan dalam Pasal 45 UU ayat (2) UU Nomor 32 Tahun 2009 dijelaskan bahwa kriteria kinerja perlindungan dan pengelolaan lingkungan hidup meliputi, antara lain, kinerja mempertahankan kawasan koservasi dan penurunan tingkat pencemaran dan/atau kerusakan lingkungan hidup. Sedangkan Pasal 46 UU Nomor 32 Tahun 2009 mengamanatkan dengan menyatakan:

"Selain ketentuan sebagaimana dimaksud dalam Pasal 45, dalam rangka pemulihan kondisi lingkungan hidup yang kualitasnya telah mengalami pencemaran dan/atau kerusakan pada saat undang-

${ }^{44}$ Asep Warlan Yusuf, Id. 
undang ini ditetapkan, Pemerintah dan pemerintah daerah wajib mengalokasikan anggaran untuk pemulihan lingkungan hidup."

Dalam mekanisme sistem, penganggaran (budgeting) merupakan perencanaan kegiatan-kegiatan pemerintah yang dinyatakan dalam ukuran keuangan. Penganggaran melahirkan anggaran yang memainkan peran penting di dalam perencanaan, pengendalian, dan pembuatan keputusan pemerintah. Anggaran ini mampu meningkatkan koordinasi dan komunikasi antarlembaga terkait. Anggaran adalah wujud nyata komitmen pemerintah untuk menanggulangi bermacam problematika di masyarakat. Ketika pemerintah menginginkan kelestarian lingkungan, komitmen pemerintah ini direfleksikan dalam anggaran lingkungan hidup. Hal tersebut telah diamanatkan dalam Penjelasan Umum butir 9 UU Nomor 32 Tahun 2009 yang menyatakan:

"Undang-Undang ini memberikan kewenangan yang luas kepada Menteri untuk melaksanakan seluruh kewenangan pemerintahan di bidang perlindungan dan pengelolaan lingkungan hidup serta melakukan koordinasi dengan instansi lain. Melalui Undang-Undang ini juga, Pemerintah memberi kewenangan yang sangat luas kepada pemerintah daerah dalam melakukan perlindungan dan pengelolaan lingkungan hidup di daerah masing-masing yang tidak diatur dalam Undang-Undang Nomor 23 Tahun 1997 tentang Pengelolaan Lingkungan Hidup.

Oleh karena itu, lembaga yang mempunyai beban kerja berdasarkan Undang-Undang ini tidak cukup hanya suatu organisasi yang menetapkan dan melakukan koordinasi pelaksanaan kebijakan, tetapi dibutuhkan suatu organisasi dengan portofolio menetapkan, melaksanakan, dan mengawasi kebijakan perlindungan dan pengelolaan lingkungan hidup. Selain itu, lembaga ini diharapkan juga mempunyai ruang lingkup wewenang untuk mengawasi sumber daya alam untuk kepentingan konservasi. Untuk menjamin terlaksananya tugas pokok dan fungsi lembaga tersebut dibutuhkan dukungan pendanaan dari anggaran pendapatan dan belanja negara yang memadai untuk Pemerintah dan anggaran pendapatan dan belanja daerah yang memadai untuk pemerintah daerah." 
Berdasarkan ketentuan tersebut, instansi yang menyelenggarakan urusan pemerintahan di bidang perlindungan dan pengelolaan lingkungan hidup membutuhkan dukungan pendanaan dari anggaran pendapatan dan belanja negara yang memadai untuk Pemerintah dan anggaran pendapatan dan belanja daerah yang memadai untuk pemerintah daerah. Guna memperjelas uraian green constitution, green legislation dan green budgeting di atas, dan untuk lebih mempermudah pembacaan, dapat dilihat melalui Gambar 3.

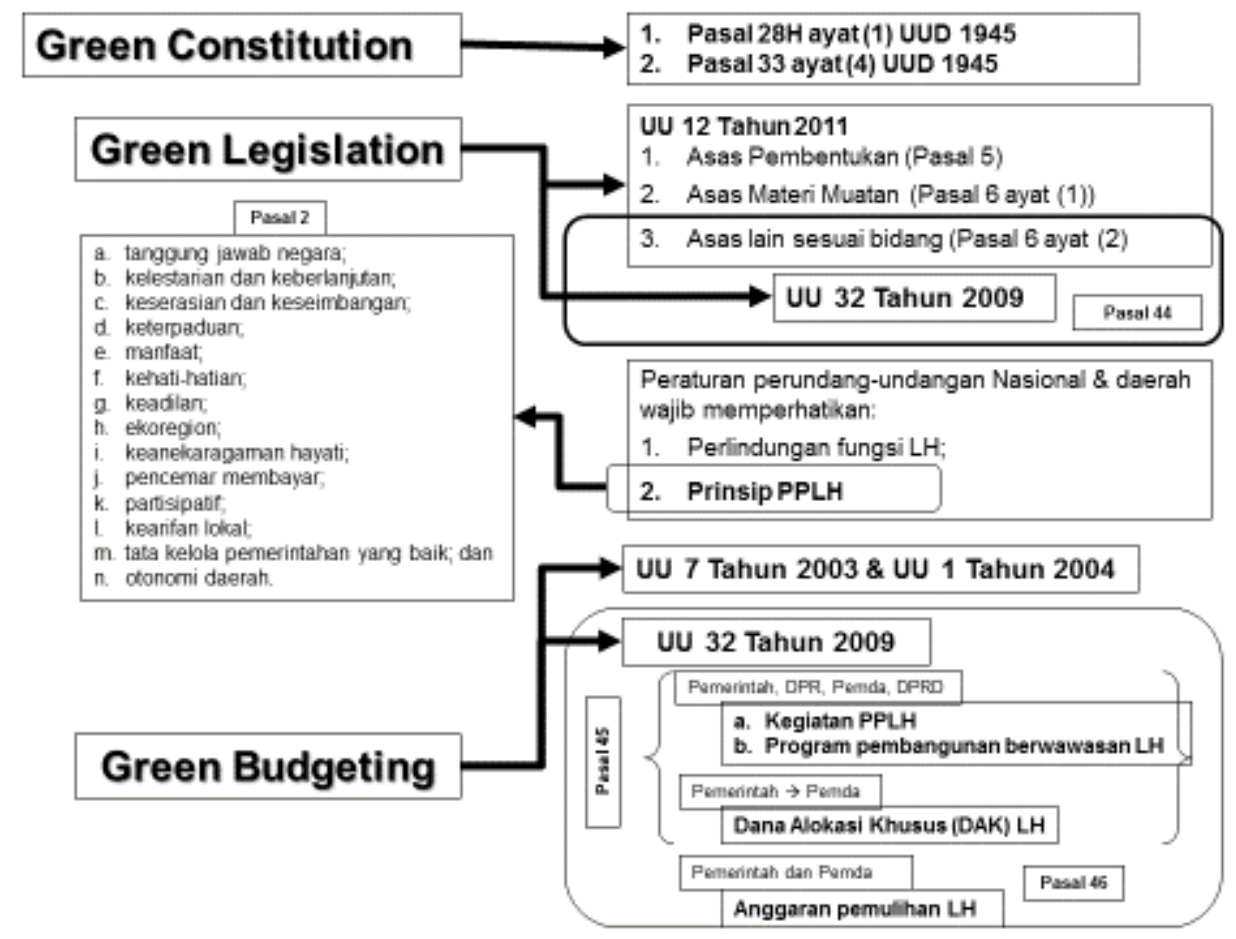

Gambar 3: Green Constitution, Green Legislation serta Green Budgeting.

\section{Penutup}

Prinsip hijau yaitu memiliki komitmen terhadap lingkungan sebagai bagian dari ideologi yang lebih luas yang menempatkan hubungan kemanusiaan dengan dunia alam sebagai dasar, dengan konsekuensi meningkatkan efisiensi dalam aktivitas pembangunan tanpa mengorbankan kelestarian lingkungan. Kegandrungan kita terhadap segala sesuatu yang ramah lingkungan merepresentasikan tahap transisi (a transitional stage), yaitu munculnya kesadaran terhadap dampak ekologis tetapi masih kurang dalam hal ketepatan, 
kedalaman pemahaman, serta kejelasan. Umumnya apa yang digemborgemborkan sebagai "hijau” pada kenyataannya hanya suatu fantasi atau sesuatu yang dibesar-besarkan. Standar "kehijauan" yang sekarang ada itu mungkin kelak akan dianggap eko-miopia (eco-myopia), yaitu pandangan yang dangkal terhadap lingkungan. Hijau adalah suatu proses (a process), bukan status, yang perlu dimaknai sebagai suatu kata kerja (a verb), bukan sebagai kata sifat (an adjective), yang mungkin dapat membantu kita untuk lebih terfokus pada upaya ramah lingkungan. Konsep hijau berkait erat dengan demokrasi hijau (green democracy) atau demokrasi ekologis (eco-democracy atau ecocracy). Konsep ekokrasi (ecocracy) harus menjadi kaidah penuntun dalam pembuatan kebijakan negara (politik hukum) dalam perlindungan dan pengelolaan lingkungan hidup. Konsep ekokrasi agar dapat dijalankan dalam sistem bernegara, maka perlu dijabarkan dalam green constitution, green legislation serta green budgeting. Green Constitution adalah penuangan kebijakan lingkungan (green policy) ke dalam teks undang-undang dasar atau konstitusi. Green Legislation adalah penuangan kebijakan lingkungan (green policy) ke dalam setiap peraturan perundangundangan yang tidak hanya dalam peraturan perundang-undangan yang terkait dengan perlindungan dan pengelolaan lingkungan hidup tetapi juga terhadap semua peraturan perundang-undangan. Green budgeting adalah suatu gagasan praktis tentang penerapan sustainable development dalam sistem anggaran, yang terintegrasi dalam suatu dokumen kebijakan yang didasarkan pada prinsip sustainability.

\section{Daftar Pustaka}

Asep Warlan Yusuf, dalam rangka Konsultasi Pemerintah Provinsi Kepulauan Riau kepada Kementerian Lingkungan Hidup terkait Penyusunan Peraturan Daerah tentang Perlindungan dan Pengelolaan Lingkungan Hidup, khususnya terkait Anggaran Berbasis Lingkungan Hidup (Green Budgeting), tertanggal 18 Agustus 2014. 
Driyarkara, Karya Lengkap Driyarkara: Esai-Esai Filsafat Pemikir yang Terlibat Penuh dalam Perjuangan Bangsanya (PT. Gramedia Pustaka Utama, Jakarta, 2006).

Dryzek, John S., Deliberative Democracy and Beyond, (Oxford University Press, New York, 2000).

Eckersley, Robert, Environmentism and Political Theory, (State University of New York Press, Albany, 1992).

Eko Nurmardiansyah, Pengembangan Kesadaran Terhadap Keadilan Lingkungan (Environmental Justice) Melalui Penataan Sistem Hukum Berdasarkan Pendekatan Sistem (Systems Approach), Disertasi, Doktor Ilmu Hukum, Program Pascasarjana Universitas Katolik Parahyangan, Bandung, 2014.

Friedman, Thomas L., Hot, Flat, and Crowded: Why We Need Green Revolution, (PT. Gramedia Pustaka Utama, Jakarta, 2009).

Gidden, Anthony, Beyond Left and Right: the Future of Radical Politics (Stanford University Press, Stanford, 1994).

Goleman, Daniel, Ecological Intelligence: The Coming Age of Radical Transparency, (Penguin Books Ltd, London, England, 2009).

Hadi S. Alikodra, Konservasi Sumberdaya Alam dan Lingkungan: Pendekatan Ecosophy bagi Penyelamatan Bumi (Gadjah Mada University Press, Yogyakarta, 2012).

Jimly Asshiddiqie, Green Constitution: Nuasa Hijau Undang-Undang Dasar Negara Republik Indonesia Tahun 1945, (PT. RajaGrafindo Persada, Jakarta, 2009).

Lafferty, William M. and Meadowcroft, James, Democracy and the Environment: Problems and Prospects, (Edward Elgar Publishing Limited, UK, 1996).

Larderel, Jacqueline Aloisi de, after working for 15 years in the French Ministry of Environment, joined the United Nations Environment Programme (UNEP) in 1987 and assumed the position as Director of the Division of Technology, Industry and Economics (DTIE) until she retired in 2003. In 2001 she was also appointed Assistant Executive Director of UNEP.

Majda El Muhtaj, Dimensi-dimensi HAM: Mengurai Hak Ekonomi, Sosial, dan Budaya, (PT. RajaGrafindo Persada, Jakarta, 2009).

Mas Achmad Santosa, Hak Asasi Manusia dan Lingkungan Hidup, dalam ICEL Staff Articles, Indonesian Center for Environmental Law (ICEL), Jakarta.

Masyhur Effendi, Prinsip-prinsip Dasar HAM dan Hukum Lingkungan Hidup, (FH Universitas Brawijaya, Malang, 1986).

Masyhur Effendi dan Taufani Sukmana Evandri, HAM Dalam Dimensi/Dinamika Yuridis, Sosial, Politik (Hukum Hak Asasi Manusia) Dalam Masyarakat, (Ghalia Indonesia, Bogor, 2007).

Miller, Norman, Environmental Politics: Interest Groups, the Media, and the Making of Policy, (Lewis Publishers, United States of America, 2002).

Munajat Danuseputro, Hukum Lingkungan, Global, (Bina Cipta, Bandung, 1982).

Nirwono Joga, Gerakan Kota Hijau, (Gramedia Pustaka Utama, Jakarta, 2013).

Sonny Keraf, Etika Lingkungan Hidup, Buku Kompas, Jakarta, 2010. 
Susi Dwi Harijanti, Ombudsman dan The Right to Good Administration, dalam Elly Erawaty, dkk. (editor), Liber Amicorum untuk Prof. Dr. CFG. Sunaryati Hartono, S.H., (Penerbit PT. Citra Aditya Bakti, Bandung, 2011).

Tomuschat, Christian, Human Rights Between Idealism and Realism (Oxford University Press, Oxford, 2003).

Weston, Burns H., Richard A. Falk, dan Anthony D'Amato, International Law and World Order: A Problem - Oriented Coursebook, (Saint Paul, West Publishing Co, 1990).

Yudi Latif, Negara Paripurna: Historisitas, Rasionalitas, dan Aktualitas Pancasila, (PT. Gramedia Pustaka Utama, Jakarta, 2011). 